\title{
Effect of climate change and some agrotechnical factors on the yield and nitrogen- and water-use efficiency in winter wheat (Triticumaestivum L.) production
}

\author{
Peter Pepó \\ University of Debrecen Faculty of Agricultural and Food Sciences and Environmental Management Institute of \\ CropSciences, Hungary
}

\begin{abstract}
Winter wheat is a very important cereal crop in Hungary ( $25 \%$ of Hungarian arable land). In the last decades in conventional wheat production used huge industrial, external inputs to increase the yields which caused a lot of harmful environmental effects. In longterm experiments different ecological (crop year), genetical (variety) and agrotechnical (fertilization, crop rotation) factors were studied on chernozem soil in Eastern Hungary. The fertilizer responses of wheat varieties depended on crop year (6.5-8.9 t ha-1 maximum yields in 2011-2015 years) and the genotypes (in 2012 the difference was $\sim 3$ that among varieties). The optimum $\mathrm{N}(+P K)$ doses varied between 30-150 $\mathrm{kg} \mathrm{ha}^{-1}$ in different crop years. In wheat production the fertilization resulted the highest yield surpluses in average crop years (2.8-5.5 $\left.t \quad h a^{-1}\right)$ comparing with dry ones (2.9-3.7 $\left.t \quad h a^{-1}\right)$, respectively. The optimum fertilization could improve WUE in wheat production.
\end{abstract}

Keywords-crop rotation, crop year, efficiency, fertilization, wheat.

\section{INTRODUCTION}

Significant yield increases of small grain cereals (including wheat) have been achived from 1970's years in the developed and developing countries (called "green revolution"). These yield incensements were based on the huge industrial, chemical inputs (fertilizers, pesticides, gasoline etc.). This "industry-like" crop production resulted high yields and enormous harmful environmental effects and less agronomy and energy efficiency [1-3]. Traditional cereal production uses a lot of external inputs to achieve high yields [4]. Winter wheat has a determinative role in Hungarian crop production. The sowing area of wheat is about 1.0 million hectars $(\sim 25 \%$ of Hungarian arable land) and the country-average yield varies from 3.5-5.5 $\mathrm{t} \mathrm{ha}^{-1}$ depending on crop years. Many foreign and Hungarian experimental results proved that climatic conditions of crop years strongly modified the yield of wheat [5-6]. The yield-losses and yield fluctuation of wheat caused by crop year (climate change) depended on soil conditions, the stress-tolerance of genotypes [7] and the agrotechniques. According to literature [8-9] the yield decreases of cereals varied between $2-55 \%$. In sustainable wheat production nutrient supply, fertilization is a key agrotechnical element [1013]. It is possible to reduce the unfavourable, negative agrotechnical, weather effects by using optimum nutrient supply, fertilization and appropriate variety-selection [9]. Because of climate change the water saving crop management and water use efficiency are especially important in cereal production. [14] built up a conceptual model of the factors impacting on water use of different users, including drivers and barriers to water saving.

The aim of this study was to evaluate the long-term experimental date on chernozem soil in Eastern-Hungary and to show the effect of climatic conditions (crop year) and nutrient-supply (fertilization) and genotype (varietyselection) on the yield of wheat. We wanted to study the nitrogen- and water-use efficiencies in wheat production.

\section{MATERIAL AND METHODS}

Our long-term experiment was set up in 1983 on a chernozem soil in Hajdúság (East-Hungary). The experimental location is found on Látókép Research Farm, $15 \mathrm{~km}$ of Debrecen (latitude: 47030', longitude: 2130', elevation above the Adriatic see: $118 \mathrm{~m}$ ).

Analytical data for initial soil conditions showed that as regards its soil physics the area can be classified as having loam soil with nearly neutral $\mathrm{pH}$ value $\left(\mathrm{pH}_{\mathrm{KCl}}\right.$ 6.46). It has medium humus content $(2.76 \%$ in the $0-0.2$ $\mathrm{m}$ upper soil layer) and a humus layer of about $0,8 \mathrm{~m}$. Its phosphorous and potassium supplies can be regarded medium ( $\mathrm{AL}-\mathrm{P}_{2} \mathrm{O}_{5} 133 \mathrm{mg} \mathrm{kg}^{-1}$ ) and good ( $\mathrm{AL} \mathrm{K} \mathrm{K}_{2} \mathrm{O} 240$ $\mathrm{mg} \mathrm{kg}^{-1}$ ), respectively. The long-term experiment had a split-plot arrangement with four repetitions. In the experiment control treatment and equidistantly increasing 
NPK doses were applied (the basic dose was $\mathrm{N}=30 \mathrm{~kg}$ ha ${ }^{1}, \mathrm{P}_{2} \mathrm{O}_{5}=22.5 \mathrm{~kg} \mathrm{ha}^{-1}, \mathrm{~K}_{2} \mathrm{O}=26.5 \mathrm{~kg} \mathrm{ha}^{-1}$ and its two-, three-, four- and five hold).

The other long-term experiment was set up in 1983 on chernozem soil on the Látókép Research Station of the University of Debrecen in the Hajdúság region (Eastern Hungary). The following factors were examined in the long-term experiment:

- crop rotation: biculture (maize, wheat), triculture (pea-wheat-maize)

- fertilization: control, $\mathrm{N}=50 \mathrm{~kg} \mathrm{ha}{ }^{-1} \mathrm{P}_{2} \mathrm{O}_{5}=35$ $\mathrm{kg} \mathrm{ha}^{-1}, \mathrm{~K}_{2} \mathrm{O}=40 \mathrm{~kg} \mathrm{ha}^{-1}$, and 2-3-4 folds of this dose

- $\quad$ irrigation: irrigated and non irrigated.

\section{RESULTS AND DISCUSSIONS}

The basic element of sustainable wheat production is to select the suitable, adaptable genotypes into agroecological and agrotechnical conditions. The nutrient supply and fertilization have the key-role in the sustainable wheat production because on the one hand fertilization directly and indirectly modifies all other agrotechnical factors (crop protection etc.) and the other hand the over-optimum fertilization causes different harmful effects $\left(\mathrm{NO}_{3}-\mathrm{N}\right.$ accumulation in different soil layers etc.). Our long-term experimental results proved that weather conditions (mainly the rainfall quantity and its distribution) strongly modified the yields of winter wheat genotypes even on chernozem soil characterized by excellent water- and nutrient husbandry. In the average of wheat varieties and crop years the yield was $7631 \mathrm{~kg} \mathrm{ha}^{-1}$ but the yields varied depending on the crop years (Table 1). The minimum yield was in $2013\left(6514 \mathrm{~kg} \mathrm{ha}^{-1}\right)$ and we got the maximum yield in $2015\left(8921 \mathrm{~kg} \mathrm{ha}^{-1}\right)$. The winter wheat genotypes could differently adapt to the crop year. According to our long-term experimental data we could state that the differences among the varieties were about 3 $\mathrm{t} \mathrm{ha}^{-1}$ in the same agrotechnical conditions (in 2012 the yields varied between 6075-8919 $\mathrm{kg} \mathrm{ha}^{-1}$ ). The crop year (mainly the water supply during the vegetation period) can modify the optimum N+PK doses, too. In crop year characterized by average water supply the optimum $\mathrm{N}+\mathrm{PK}$ doses varied between $\mathrm{N}=90-150 \mathrm{~kg} \mathrm{ha}^{-1}+\mathrm{PK}$ and in crop year after very mild winter the $\mathrm{N}_{\text {opt }}+\mathrm{PK}$ dropped down to $\mathrm{N}=30-60 \mathrm{~kg} \mathrm{ha}^{-1}+\mathrm{PK}$ (because of very high mineralization of organic matter in the chernozem soil).

Table.1: Fertilizer response of winter wheat genotypes in different crop years

(Debrecen, chernozem soil, 2011-2015)

\begin{tabular}{lcccccc}
\hline \multicolumn{1}{c}{ Variety } & $2011\left(\mathrm{~N}_{\mathrm{opt}}\right)$ & $2012\left(\mathrm{~N}_{\mathrm{opt}}\right)$ & $2013\left(\mathrm{~N}_{\mathrm{opt}}\right)$ & $2014\left(\mathrm{~N}_{\mathrm{opt}}\right)$ & $2015\left(\mathrm{~N}_{\mathrm{opt}}\right)$ & Average \\
\hline GK Öthalom & $6819_{(150)}$ & $6175_{(150)}$ & $5983_{(150)}$ & $8713_{(30)}$ & $8862(150)$ & 7310 \\
Pannonikus & $8123_{(90)}$ & $8139_{(150)}$ & $6576_{(150)}$ & $7996_{(30)}$ & $8864(90)$ & 7940 \\
Euclide & $9586_{(150)}$ & $8919_{(150)}$ & $7590_{(150)}$ & - & - & 8698 \\
GK Csillag & - & $7263_{(150)}$ & $6562_{(150)}$ & $8350_{(60)}$ & $9150(150)$ & 7831 \\
Bitop & - & $6075_{(150)}$ & $6089_{(120)}$ & $6663_{(30)}$ & - & 6276 \\
GK Békés & - & $7917_{(150)}$ & $6281_{(120)}$ & $7915_{(30)}$ & $8809(90)$ & 7731 \\
Average & 8176 & 7415 & 6514 & 7927 & 8921 & 7631 \\
Yield interval, t/ha & $6.8-9.6$ & $6.1-8.9$ & $6.0-7.6$ & $6.7-8.4$ & $8.8-9.2$ & $6.3-8.7$ \\
Min-Max, \% & $83-117$ & $82-120$ & $92-117$ & $84-105$ & $99-103$ & $82-114$ \\
Interval of yield fluctuation, \% & 34 & 38 & 25 & 21 & 4 & 32 \\
Interval of $\mathrm{N}_{\text {opt }}$ kg ha ${ }^{-1}$ & $90-150$ & $120-150$ & $120-150$ & $30-60$ & $90-150$ & $90-128$ \\
LSD $_{5 \%}$ & 457 & 355 & 600 & 674 & 614 & - \\
\hline
\end{tabular}

The winter wheat is one of the best fertilizer-responding field crops. Our long-term experimental data proved that the fertilization of wheat resulted good yield surpluses on chernozem soil characterized by excellent natural nutrient stock (Table 2). The yield surpluses of wheat varied between $2659 \mathrm{~kg} \mathrm{ha}^{-1}(2013 / 2014$ crop year) and $6020 \mathrm{~kg}$ ha $^{-1}(2015 / 2016$ crop year). The yields of control treatment proved the excellent natural nutrient avaibility of chernozem soil (1816 kg ha $\mathrm{k}^{-1}$ and $\left.5897 \mathrm{~kg} \mathrm{ha}^{-1}\right)$. The other meteorological parameters could modify the yield surplus of wheat genotypes (in 2013 the strong and long frosting period in March decreased the yields, in 2014 the very mild winter period accelerated the $\mathrm{N}$-mineralization in chernozem soil). 
Table.2: Effect of crop year on the control and maximum yield of winter wheat

(Debrecen, 1999-2017) (average of varieties)

\begin{tabular}{lcccccc}
\hline Crop year & $\begin{array}{c}\text { Control } \\
\text { yield } \\
\mathrm{kg} \mathrm{ha}^{-1}\end{array}$ & $\begin{array}{c}\text { Maximum } \\
\text { yield } \\
\mathrm{kg} \mathrm{ha}^{-1}\end{array}$ & $\begin{array}{c}\text { Yield- } \\
\text { surplus } \\
\mathrm{kg} \mathrm{ha}^{-1}\end{array}$ & $\begin{array}{c}\text { Rainfall in } \\
\text { veg. period } \\
(\mathrm{mm})\end{array}$ & $\begin{array}{c}\text { Rainfall deviation from } \\
\text { 30 year average }(\mathrm{mm})\end{array}$ & $\begin{array}{c}\mathrm{N}_{\text {opt }}(+\mathrm{PK}) \\
\mathrm{kg} \mathrm{ha}^{-1}\end{array}$ \\
\hline $2010 / 2011$ & 4023 & 8043 & 4020 & 340.9 & -60.0 & 133 \\
$2011 / 2012$ & 3906 & 7303 & 3397 & 320.7 & -80.2 & 144 \\
$2012 / 2013$ & 1816 & 6674 & 4858 & 480.2 & +79.3 & 145 \\
$2013 / 2014$ & 5897 & 8556 & 2659 & 284.0 & -116.9 & 49 \\
$2014 / 2015$ & 4662 & 9024 & 4362 & 350.9 & -50.0 & 110 \\
$2015 / 2016$ & 3927 & 9947 & 6020 & 561.7 & +160.81 & 115 \\
$2016 / 2017$ & 5226 & 8028 & 2802 & 379.6 & -21.3 & 133 \\
\hline
\end{tabular}

Wheat is a sensitive arable crop to agroecological and agrotechnical factors. Our multifactorial long-term experimental data (between 1986-2017) proved that the effects of fertilization were different depending on the crop rotation and the weather of crop year. In Eastern Hungary characterized by continental climate the precipitation quantity and its distribution are the decisiveagroecological factor on chernozem soil. The effects of crop year were significant on the yields of wheat in different (bi- and triculture) crop rotation (Table $3)$. We obtained the strongest effect of crop year in biculture (the yields of wheat varied between 1892-3162 $\mathrm{kg} \mathrm{ha}^{-1}$ in control and 5419-8029 $\mathrm{kg} \mathrm{ha}^{-1}$ in $\mathrm{N}_{\mathrm{opt}}+\mathrm{PK}$, respectively). In diversed crop rotation (triculture) the yield-fluctuations of wheat were less (in control 4426$5763 \mathrm{~kg} \mathrm{ha}^{-1}$, in $\mathrm{N}_{\text {opt }}+\mathrm{PK} \quad 6190-8600 \mathrm{~kg} \mathrm{ha}^{-1}$, respectively). The efficiency of fertilization was modified by crop year and crop rotation. The highest yield surpluses of wheat were obtained in average crop year in different crop rotation, but the efficiency of nutrient supply was much higher in biculture (5513 $\mathrm{kg} \mathrm{ha}^{-1}$ ) comparing with triculture $\left(2837 \mathrm{~kg} \mathrm{ha}^{-1}\right)$. The optimum $\mathrm{N}$ $(+\mathrm{PK})$ doses were much lower $\left(\mathrm{N}_{\mathrm{opt}}=50-100 \mathrm{~kg} \mathrm{ha}^{-1}\right.$ $+\mathrm{PK})$ in triculture than in biculture $\left(\mathrm{N}_{\mathrm{opt}}=150-200 \mathrm{~kg}\right.$ ha

$\left.{ }^{1}+\mathrm{PK}\right)$ because of peas forecrop.

Table.3: Effect of crop year, crop rotation and fertilization on the yield of wheat in long-term experiment (Debrecen, chernozem soil, 1986-2017)

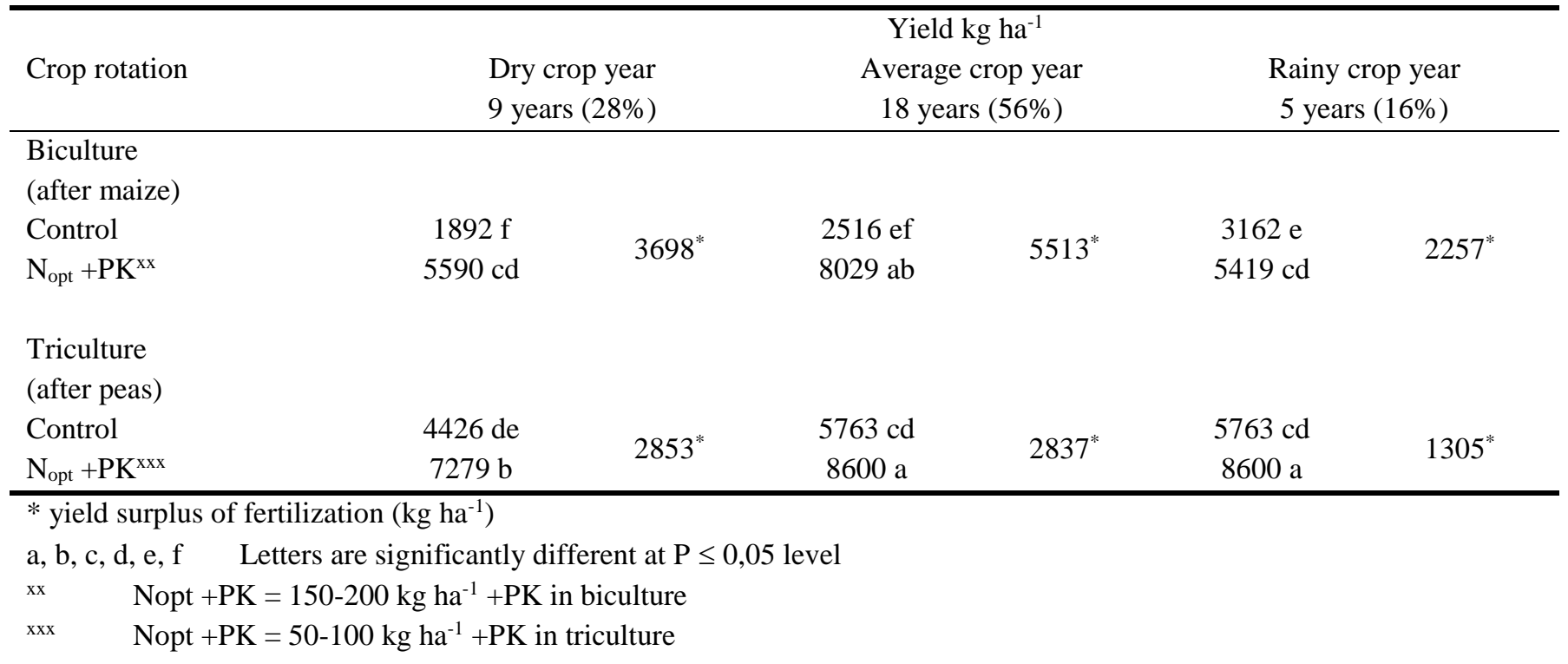

Our long-term experimental data proved that the using optimum fertilizer doses $(\mathrm{N}+\mathrm{PK})$ can increase the water use efficiency (WUE $=\mathrm{kg}$ yield $/ 1 \mathrm{~mm}$ rainfall in vegetation period) of wheat both in dry and average crop years (Table 4). In different crop rotation the WUE of control varied between $6.00-16.57 \mathrm{~kg} \mathrm{~mm}^{-1}$ in dry and $6.00-09.27 \mathrm{~kg} \mathrm{~mm}^{-1}$ in average crop years, respectively. In optimum $\mathrm{N}+\mathrm{PK}$ treatment the WUE values were much higher (21.31-24.04 kg mm $\mathrm{md}^{-1}$ and 24.71-29.48 kg mm $\mathrm{mm}^{-1}$, respectively). 
Table.4: Water use efficiency (WUE) of wheat in different crop years

(Debrecen, chernozem soil, non irrigated)

\begin{tabular}{lccc}
\hline \multirow{2}{*}{ Crop rotation } & \multirow{2}{*}{ Fertilizer treatment } & Dry crop year & Average crop year \\
\cline { 2 - 4 } & & yield kg/1 mm rainfall in vegetation period \\
\hline \multirow{2}{*}{ Biculture } & Control & $6.03 \mathrm{~d}$ & $6.00 \mathrm{~d}$ \\
& $\mathrm{~N}_{\mathrm{opt}}+\mathrm{PK}$ & $21.31 \mathrm{bc}$ & $24.71 \mathrm{~b}$ \\
& & & \\
\multirow{2}{*}{ Triculture } & Control & $16.57 \mathrm{~cd}$ & $19.27 \mathrm{c}$ \\
& $\mathrm{N}_{\mathrm{opt}}+\mathrm{PK}$ & $24.04 \mathrm{bc}$ & $29.48 \mathrm{a}$ \\
\hline
\end{tabular}

$\mathrm{a}, \mathrm{b}, \mathrm{c}, \mathrm{d} \quad$ Letters are significantly different at $\mathrm{P} \leq 0,05$ level

\section{CONCLUSIONS}

Our long-term experiments proved that we have to harmonize the ecological, biological and agrotechnical factors to increase the nutrient- and water-use efficiency and decrease the harmful environmental effects in wheat production. According to our fidings there were huge differences among the maximum yields and the optimum $\mathrm{N}+\mathrm{PK}$ doses of winter wheat genotypes. The wheat varieties differently responded to the $\mathrm{N}+\mathrm{PK}$ fertilizer doses and they differently utilized the natural nutrient sources of chernozem soil. The yields of wheat varieties varied between $6075-9586 \mathrm{~kg} \mathrm{ha}^{-1}$ and the Nopt $+\mathrm{PK}$ doses fluctuated between $\mathrm{N}=30-150 \mathrm{~kg} \mathrm{ha}^{-1}+\mathrm{PK}$ depending the crop year (mainly water supply) and genotypes. So under climatic change the optimum fertilization is a key-element to change the conventional wheat production into a sustainable one $[1-2,5,15]$. Monitoring the sustainability of wheat production needs different indicators [16]. The nutrient- and water-use efficiency were modified by crop year, crop rotation and fertilization. We obtained the highest yield surpluses of wheat in average crop year, in diversified crop rotation with using less $\mathrm{N}_{\mathrm{opt}}+\mathrm{PK}$ doses $\left(\mathrm{N}=50-100 \mathrm{~kg} \mathrm{ha}^{-1}+\mathrm{PK}\right)$ comparing with the dry and rainy crop years, simplified crop rotation (biculture) simiraly to [17], [18] and [13]. A nutrient (mainly nitrogen) efficiency was modified by climatic factors, genotypes and agrotechnical elements [19-22]. The water use efficiency of wheat (WUE) was better in triculture and Nopt $+\mathrm{PK}$ treatment (in control 16.57-19.27 kg mm${ }^{-1}$, in Nopt +PK 24.04-29.48 kg mm${ }^{-1}$ ) than in biculture $\left(6.00-6.03 \mathrm{~kg} \mathrm{~mm}^{-1}\right.$ and $21.31-24.71 \mathrm{~kg}$ $\mathrm{mm}^{-1}$, respectively) crop rotation. The optimum $\mathrm{N}+\mathrm{PK}$ fertilization could increase the WUE of wheat.

\section{ACKNOWLEDGEMENT}

The publication is supported by the EFOP-3.6.3-VEKOP16-2017-00008 project. The project is co-financed by the European Union and the European Social Fund.

\section{REFERENCES}

[1] Austin, R.B. (1999): Yield of wheat in the United Kingdom: recent advances and prospects. Crop Science. 39, 6: 1604-1610.

[2] Pepó, P. (2007): The role of fertilization and genotype in sustainable winter wheat (Triticumaestivum L.) production. Cereal Research Communications. 35, 2: 917-920.

[3] Olesen, J.E., Trnka, M., Kersebaum, K.C., Skjelvag, A.O., Seguin, B., Peltonen-Sainio, P., Rossi, F., Kozyra, J., Micale, F. (2011): Impacts and adaptation of European crop production systems to climate change. European Journal of Agronomy. 34, 2: $96-112$.

[4] Hole, D.G., Perkins, A.J., Wilson, J.D., Alexander, H.I., Grice, P.V., Evans, A.D. (2005): Does organic farming benefit biodiversity? Biological Conservation. 122: 113-130.

[5] Bala, P., Sikder, S. (2017): Growth of Wheat Genotypes Influenced by Heat Stress. International Journal of Environment, Agriculture and Biotechnology. 2, 4: 1863-1878.

[6] Pepó, P., Györi, Z. (2005). A study of the yield stability of winter wheat varieties. Cereal Research Communications, 33(4), 769.

[7] Alsalimiya, M., De Luigi, G., Abu-Rabada, E., Ayyad, H., Basheer-Salimia, R. (2018): Adaption of wheat genotypes to drought stress. International Journal of Environment, Agriculture and Biotechnology. 3, 1: 182-186.

[8] Shen, S.H., Gao, W.Y., Li, B.B. (1999): Water consumption and its impact on the yield of winter wheat in Xifeng. Journal of Nanjiing Institute of Meteorology, 22, 1: 88-94.

[9] Pepó, P. (2009): Effects of water supply as an abiotic stress on the yields and agronomic traits of winter wheat (Triticumaestivum L.) on chernozem soil. Cereal Research Communication, 37, Supplement: 29-32.

[10] Jordan, V.W.L., Hutcheon, J.A., Donaldson, G.V., Farmer, D.P. (1997): Research into and development 
of integrated farming systems for less-intensive arable crop production: experimental progress (1989-1994) and commercial implementation. Agriculture Ecosystems and Environment. 64, 2: 141-148.

[11] Oehl, F., Frossard, E., Fliessbach, A., Dubois, D., Oberson, A. (2004): Basal organic phosphorus mineralization in soils under different farming systems. Soil Biology and Biochemistry. 36: 667675.

[12]Keller, M., Oberson, A., Annaheim, K.E., Tamburini, F., Maeder, P., Mayer, J., Frossard, E., Buenemann, E.K. (2012): Phosphorus forms and enzymatic hydrolyzability of organic phosphorus in soils after 30 years of organic and conventional farming. Journal of Plant Nutrition and Soil Science. 175, 3: 385-393.

[13] Khatri, N., Chalise, D.R., Rawal, N. (2017): Short term effect of crop residue and different nitrogen levels on grain yield of wheat under rice-wheat system. International Journal of Environment, Agriculture and Biotechnology. 2, 4: 1689-1693.

[14] Graymore, M.L.M., Wallis, A.M. (2010): Water savings or water efficiency? Water-use attitudes and behaviour in rural and regional areas. International Journal of Sustainable Development \& World Ecology. 17, 1: 84-93.

[15] Maye, J., Gunst,, L., Mäder, P., Samson, M-F., Carcea, M., Narducci, V., Thomsen, I., Dubois, D. (2015): Productivity, quality and sustainability of winter wheat under long-term conventional and organic management in Switzerland. European Journal of Agronomy. 65: 27-39.

[16]Barrios, E.B., Sarte, G.Ma.F. (2008): Monitoring sustainable agriculture in Southeast Asia. International Journal of Sustainable Development \& World Ecology, 15, 2: 95-102.

[17] Dobermann, A. (2005): Nitrogenuseefficiency: State of the art. IFA International WorkshoponEnhancedEfficiencyFertilizers, Frankfurt. 28-30 June. International FertilizerIndustryAssociation (FIA), Paris, France, 1-16.

[18] Noureldin, N.A., Saudy, H.S., Ashmawy, F., Saed. H.M. (2013): Grainyieldresponse index of breadwheatcultivarsasinfluencedbynitrogenlevels. Annals of Agricultural Science 58:147-152.

[19] Sieling, K., Schroder, H., Finck, M., Hanus, H. (1998): Yield, N uptake, and apparentNuseefficiency of winterwheat and winterbarleygrownindifferentcroppingsystems. Journal of Agricultural Science131:375-387.

[20] Hatfield, J.L., Prueger, J.H. (2004): Nitrogenoveruse, under-use, and efficiency. Proceedings of the $4^{\text {th }}$
International Crop Science Congress, Brisbane, Australia. 26 September-1 October 2004. The Regional Institute Ltd., Gosford, New South Wales, Australia.

[21]Bertic, B., Loncaric, Z., Vukadinovic, V., Vukobratovic, Z., Vukadinovic, V. (2007): Winter wheatyieldresponsestomineralfertilization. Cereal Research Communications 35:245-248.

[22] Li, L., Hong, J.P., Wang, H.T., Xiu, Y.H., Zhang, L. (2013): Effects of watering and nitrogenfertilizationonthegrowth, grainyield, and water- and nitrogenuseefficiency of winterwheat. Chinese Journal of AppliedEcology 24:1367-1373. 